\title{
Cegah Penyakit ISPA di Puskesmas Kecamatan Limapuluh Kota Pekanbaru
}

\author{
Yuyun Priwahyuni*, Christine Vita Gloria, Agus Alamsyah, Ikhtiyaruddin, \\ Iqlima Afif Azizah, Erisca Feroza \\ Prodi Kesehatan Masyarakat, STIKes Hang Tuah Pekanbaru \\ email: yuyun.priwahyuni@gmail.com
}

\begin{abstract}
Acute respiratory syndrome infection (ARS) is top and bottom respiratory canal disease which caused by infectious agent. Environment based diseases are still the main cause of death in Indonesia. Acute Respiratory Infection in Indonesia is on the top 10 list of diseases in hospitals. The cause of Acute Respiratory Infection includes with the environmental conditions of the patient's residence. The purpose of PKM is to increase public knowledge and understanding of how to recognize the risk factors of Acute Respiratory Infections. The PKM methods are counselling and health education about recognizing the risk factors of Acute Respiratory Infections, the target of PKM is the community at Limapuluh Health Center in Pekanbaru City. The activity was held on Saturday, November 30, 2019. The results of PKM activities were obtained that from 50 people who participated in the activity, $80 \%$ were able to know and understand about Acute Respiratory Infection (ARI) and 40\% were able to understand about how to prevent and treat ARI.
\end{abstract}

Kata Kunci: ARI, Limapuluh Health Center

\section{Abstrak}

Infeksi Saluran Pernapasan Akut (ISPA) merupakan penyakit saluran pernapasan atas atau bawah yang disebabkan agen infeksius. Penyakit-penyakit berbasis lingkungan memang masih merupakan penyebab utama kematian di Indonesia. Penyakit ISPA di Indonesia berada pada 10 daftar penyakit terbanyak di rumah sakit. penyebab ISPA berkaitan dengan kondisi lingkungan tempat tinggal penderita. Tujuan PKM adalah untuk meningkatkan pengetahuan dan pemahaman masyarakat bagaimana mengenali faktor resiko penularan penyakit ispa. Metode PKM penyuluhan dan pendidikan kesehatan tentang faktor resiko terserang penyakit ISPA dan pecegahan dari penularannya, sasaran PKM masyarakat di Puskesmas Kecamatan Limapuluh Kota Pekanbaru. Kegiatan dilaksanakan Sabtu 30 November 2019. Hasil kegiatan PKM didapat bahwa dari 50 masyarakat yang mengikuti kegiatan tersebut, $80 \%$ masyarakat mengetahui penyakit ISPA dan 40\% memahami cara pencegahan dan pengobatan penyakit ISPA

Kata Kunci: ISPA, Puskesmas Kecamatan Limapuluh

\section{PENDAHULUAN}

Konsensus Pertemuan Ahli Infeksi Saluran Pernapasan Akut tahun (2017) menyatakan bahwa penyakit Infeksi Saluran Pernafasan Akut (ISPA) menjadi salah satu masalah kesehatan masyarakat yang penting untuk diperhatikan, karena ISPA merupakan penyakit akut dan bahkan dapat menyebabkan kematian pada balita di berbagai negara berkembang termasuk
Indonesia. Infeksi Saluran Pernafasan Akut (ISPA) merupakan salah satu penyebab utama kematian pada balita didunia. Populasi penduduk yang terus bertambah dan tidak terkendali mengakibatkan kepadatan penduduk di suatu wilayah yang tidak tertata baik dari segi aspek sosial, budaya dan kesehatan (Adesanya \& Chiao, 2017). Kondisi ini akan bertambah buruk dengan status sosial ekonomi keluarga yang 
rendah atau berada dibawah garis kemiskinan karena tidak dapat memenuhi asupan gizi yang baik dan sehat untuk balita ditambah dengan kondisi fisik rumah yang tidak layak tinggal (Kolawole, Oguntoye, Dam, \& Chunara, 2017).

Penelitian yang dilakukan Wahyuningsih (2017) menyatakan dari tahun ke tahun, prevalensi ISPA di Indonesia tetap tinggi, yaitu sekitar $21,6 \%$ di daerah perkotaan. Hasil Survei Kesehatan Rumah Tangga (SKRT) menunjukkan jumlah balita penderita pneumonia menurun dari 804.937 pada tahun 1999 menjadi 479.283 pada tahun 2000. Namun dari tahun 2000 hingga 2003 jumlah balita penderita ISPA cenderung menetap di angka yang sama meski pemerintah telah mencanangkan program pemberantasan ISPA.

Tingkat morbiditas dan mortalitas penyakit ini cukuplah tinggi terutama pada anak-anak dan balita. Penyakit gangguan pernafasan merupakan salah satu penyebab utama kematian pada balita diperkirakan mencapai 16\%. Pada tahun 2015 angka kematian yang diakibatkan oleh gangguan pernafasan sebanyak 920.136 jiwa, kejadian ini paling banyak terjadi di kawasan Asia Selatan dan Afrika (WHO, 2016). Penelitian Cakmak, Hebbern, Cakmak, \& Vanos (2016) menunjukkan penyebab terjadinya ISPA dapat dimodifikasi baik disebabkan oleh faktor lingkungan, sosial ekonomi dan perilaku, dengan cara adanya kemauan serta kerjasama antara masyarakat dengan pemerintah.

ISPA berlangsung sampai 14 hari yang dapat ditularkan melalui air ludah, darah, bersin maupun udara pernafasan yang mengandung kuman. ISPA diawali dengan gejala seperti pilek biasa, batuk, demam, bersin-bersin, sakit tenggorokan, sakit kepala, sekret menjadi kental, nausea, muntah dan anoreksia. Banyak orang tua yang sering mengabaikan gejala tersebut, sementara kuman dan virus dengan cepat berkembang di dalam saluran pernafasan yang akhirnya menyebabkan infeksi. Jika telah terjadi infeksi maka anak akan mengalami kesulitan bernafas dan bila tidak segera ditangani, penyakit ini bisa semakin parah menjadi pneumonia yang menyebabkan kematian (IDAI, 2015).

Salah satu faktor resiko terjadinya ISPA dilihat dari faktor lingkungan adalah perilaku merokok. Perilaku merokok anggota keluarga akan berdampak kepada anggota keluarga lain khususnya balita, dimana balita menyerap nikotin dua kali lebih banyak dibandingkan orang dewasa (Basuki et al, 2016). Serta balita juga memiliki sistem kekebalan tubuh yang masih rentan terhadap berbagai penyakit (Darmawan et al, 2016). Balita yang tinggal dalam rumah yang terdapat anggota keluarga yang merokok, maka balita tersebut termasuk perokok pasif yang akan menerima semua akibat buruk dari asap rokok.

Pada penelitian yang dilakukan Akinyemi \& Morakinyo (2018), menyatakan bahwa penelitian yang mereka lakukan dari tahun 2003 sampai dengan 2013 di Nigeria faktor risiko kejadian ISPA adalah kepadatan penduduk, kepadatan hunian, polusi udara dan sanitasi lingkungan yang buruk. Penelitian yang dilakukan Shibata et al (2014) di Indonesia bagian timur menyatakan bahwa faktor risiko terjadinya ISPA adalah rendahnya tingkat pengetahuan ibu tentang cara merawat anak, pemeberian ASI, pajanan asap rokok, kondisi fisik rumah akibat rendahnya tingkat pendapatan keluarga.

Berdasarkan prevalensi ISPA tahun 2016 di Indonesia telah mencapai $25 \%$ dengan rentang kejadian yaitu sekitar 17,5 $\%-41,4 \%$ dengan 16 provinsi diantaranya mempunyai prevalensi di atas angka nasional (Susanti, 2017). Jumlah penderita ISPA bukan pneumonia di kota Pekanbaru dengan umur diatas 5 tahun pada tahun 2016 berjumlah 44.492 kasus. Kasus ISPA di Puskesmas sangat tinggi salah satunya Puskesmas Harapan Raya dimana pada bulan November 2017 berjumlah 241 kasus, pada bulan Desember meningkat sebanyak $34,85 \%$ dan pada bulan Januari 
2018 meningkat sebanyak 41,49\%. Peningkatan jumlah kasus ISPA ini memerlukan pemeriksaan diagnostik yang tepat yaitu pemeriksaan kapasitas paru.

Hasil studi pendahuluan yang dilakukan peneliti pada tahun 2018 melalui wawancara kepada pasien yang datang ke Puskesmas Harapan Raya kepada 10 orang responden yang menderita ISPA dengan umur diatas 5 tahun didapatkan hasil 10 orang belum pernah melakukan pemeriksaan kapasitas paru dan 9 orang responden mengalami sesak napas dan mengganggu saat ingin tidur. Penderita mengalami ISPA berulang dalam 1 bulan terakhir berjumlah 3 orang dan 1 orang pasien yang harus dirujuk karena terjadinya obstruksi jalan napas.

ISPA yang berulang juga menyebabkan gangguan aktivitas seharihari sehingga anak tidak dapat bersekolah. Anak yang sering tidak masuk sekolah mengakibatkan terganggunya perkembangan kognitif anak, begitu juga dengan orang dewasa ISPA dapat menganggu pekerjaan (Putra \& Isnaini Herawati, 2017) .

Menurut data yang di peroleh dari Dinas Kesehatan Kota Pekanbaru, terhitung Januari hingga akhir Februari 2019 terdapat sebanyak 1.775 warga terpapar Infeksi Saluran Pernafasan Akut (ISPA). Penyebab tingginya kasus ini, selain karna kondisi cuaca di Kota Pekanbaru memasuki musim kemarau, juga akibat kabut asap dampak kebakaran hutan dan lahan meliputi Kabupaten/Kota yang ada di Kota Pekanbaru beberapa pekan terakhir ini. Dari data Dinas Kesehatan Kota Pekanbaru untuk Penderita ISPA tertinggi tercatat di Puskesmas Lima Puluh berjumlah 331 orang. Dan penderita ISPA terbanyak usia 5 tahun keatas.

\section{METODE PENGABDIAN}

Penelitian Ini memakai metode Konseling dimana Konselor memeberikan informasi Kepada Konseli/individu dengan melakukan pendekatan ke Konseli/individu tersebut kepada pasien puskesmas kecamatan lima puluh kota pekanbaru untuk mengetahui jumlah kasus ISPA pada pasien yang datang ke puskesmas kecamatan lima puluh. Populasi dalam penelitian ini adalah semua umur yang ada di puskesmas kecamatan lima puluh. Sedangkan respondennya adalah ibu-ibu, bapak-bapak serta anak-anak. Besar sampel sebanyak 331.

Data dikumpulkan peneliti diperoleh secara langsung dari responden dengan melakukan wawancara, pembagian brosur dengan materi ISPA, serta observasi. Data sekunder bersumber dari instansi tertentu yaitu Puskesmas kecamatan lima puluh kota pekanbaru. Pengambilan sampel dilakukan berdasarkan daftar pasien yang ada di puskesmas kecamatan limapuluh kota pekanbaru pada tahun 2019.

\section{HASIL DAN PEMBAHASAN}

Kegiatan Pemberdayaan Masyarakat pada tanya jawab tentang ISPA serta cara pencegahan dan pengobatan dari penyakit ISPA dilaksankan di lingkungan Puskesmas Kecamatan Lima Puluh. Jalan Sumber Sari No.15, Tj.Rhu, Kec. Lima Puluh, Kota Pekanbaru. Kegiatan diikuti oleh para pasien yang berjumlah 50 orang, kegiatan dilaksanakan pada hari Sabtu tanggal 30 November 2019 yang dimulai pukul 09.00 WIB sampai dengan selesai.

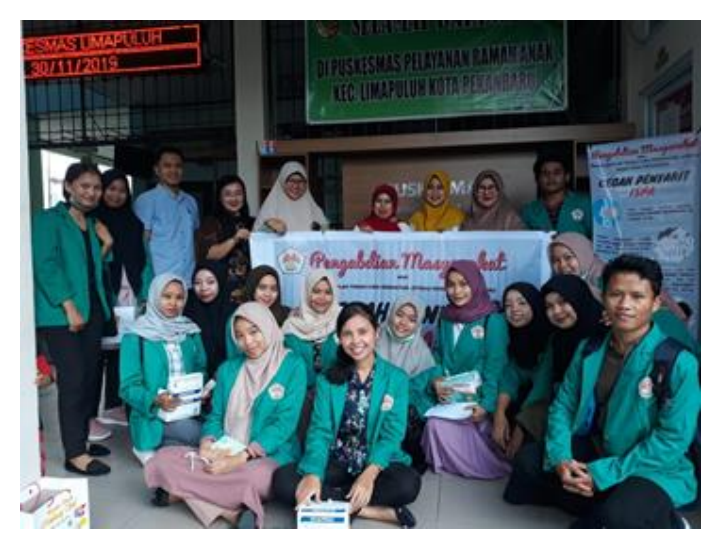

Gambar 1. Foto bersama staff Puskesmas Kecamatan Limapuluh.

Sebelum kegiatan pengabdian masyarakat dilakukan para pengabdi serta mahasiswa yang membantu proses pengabdian berfoto bersama staff 
puskesmas kecamatan limapuluh. kemudian proses pengabdian dilakukan, bentuk kegiatan pengabdian yang dilaksanakan adalah tanya jawab tentang ISPA serta cara pencegahan dan pengobatan dari penyakit ISPA berupa konseling. Praktek cuci tangan pakai sabun dan pendidikan kesehatan berupa ceramah dilakukan oleh para pegabdi dan mahasiswa STIKes Hang Tuah Pekanbaru. Sebelum para peserta yakni pasien diberikan penjelasan pencegahan dan pengobatan, para pasien diberikan pertanyaan terlebih dahulu untuk mengetahui pengetahuan pasien terkait ISPA.

Dari hasil tersebut dapat terlihat bahwa dari 50 pasien yang mengikuti kegiatan tersebut, hanya $80 \%$ pasien yang mengetahui apa itu ISPA. Setelah para pengabdi menyampaikan penjelasan pencegahan dan pengobatan. Hasil yang didapat bahwa dari 50 siswa yang mengikuti kegiatan tersebut $80 \%$ pasien memahami cara pencegahan dan pengobatan tersebut. Kegiatan Tanya jawab tentang ISPA serta pencegahan dan pengobatan dari penyakit ISPA berupa konseling sangat efektif dilaksanakan pada pasien puskesmas.

ISPA sebenarnya dapat dialami segala usia. Kondisi pada beberapa orang, seperti anak-anak di bawah usia 5 tahun hingga orang tua lebih rentan terkena ISPA. ISPA juga diartikan radang akut atas maupun bawah yang disebabkan oleh jasad renik atau bakteri, virus, maupun riketsia, tanpa atau disertai radang parenkim paru. ISPA yang mengenai saluran nafas bawah misalnya bronchitis, bila menyerang anakanak,khususnya balita akan memberikan gambaran klinik yang berat dan sering sekali berakhir dengan kematian.

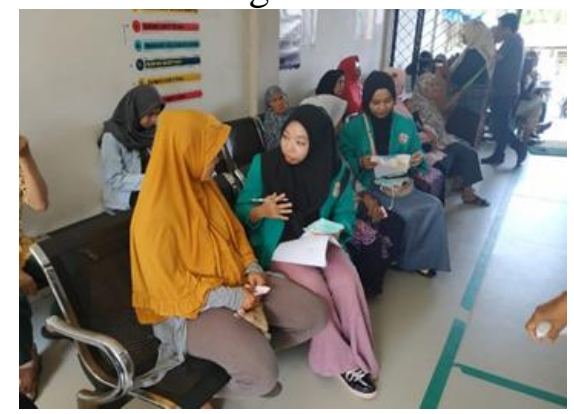

Gambar 2. Kegiatan konseling bersama masyarakat di wilayah kerja Puskesmas Kecamatan Limapuluh

Petugas pelaksana pengabdiaan Melaksanakan Pemberdayaan Masyarakat dengan tanya jawab tentang ISPA serta memberitahu pencegahan dan pengobatan dari penyakit ISPA pada pasien dengan menggunkan media leaflet untuk mempermudah proses konseling dengan pasien di Puskemas Kecamatan Lima Puluh. Jalan Sumber Sari No.15, Tj.Rhu, Kec. Lima Puluh, Kota Pekanbaru merupakan salah satu bentuk kegiatan dalam meningkatkan pengetahuan dan sikap pasien dalam menjaga kesehatan dan mencegah pasien untuk terinfeksi penyakitpenyakit.

Diagnosis ISPA oleh karena virus dapat ditegakkan dengan pemeriksaan laboratorium terhadap jasad renik itu sendiri.Pemeriksaan yang dilakukan adalah biakan virus, serologis, diagnostik virus secara langsung. Sedangkan diagnosis ISPA oleh karena bakteri dilakukan dengan pemeriksaan sputum, biakan darah, biakan cairan pleura. Pada infeksi virus, transmisi diawali dengan penyebaran virus ke daerah sekitar terutama melalui bahan sekresi hidung. Dari beberapa penelitian klinik, laboratorium dan penelitian lapangan, diperoleh kesimpulan bahwa sebenarnya kontak hand to hand merupakan modus yang terbesar bila dibandingkan dengan cara penularan aerogen yang semula banyak diduga sebagai penyebab utama.

Pencegahan ISPA dapat dilakukan dengan cara mencuci tangan sesering mungkin serta menutup mulut dan hidung pada saat batuk atau bersin. Gunakan tissue, sapu tangan, atau masker hidung saat batuk atau bersin. Langkah paling sederhana yang dapat dilakukan untuk mencegah ISPA adalah beristirahat dan memiliki pola tidur yang cukup. Selain itu, perhatikan asupan cairan agar terhindar dari dehidrasi dan tenggorokan tidak mengering. Sebaiknya juga jauhkan diri dari asap rokok karena akan memperparah kondisi ISPA. 
Konseling adalah layanan bantuan oleh tenaga profesional kepada seseorang atau kelompok individu untuk pengembangan kehidupan efektif sehari-hari yang terganggu dengan focus mandiri mandiri yang mampu mengendalikan diri melalui penyelenggaraan berbagai jenis layanan dan kegiatan pendukung dalam proses pembelajaran. Cara ini sebenarnya merupakan bagian dari bimbingan dan penyuluhan. Tanya jawan antara petugas kesehatan dengan klien untuk menggali informasi mengapa ia tidak tau atau belum menerima perubahan, ia tertarik atau belum menerima perubahan untuk mempengaruhi apakah perilaku sudah atau yang akan mempunyai dasar pengerttian dan kesadaran yang kuat.

\section{SIMPULAN}

Hasil yang dicapai melalui kegiatan Pengabdian Masyarakat tentang Cegah Penyakit ISPA adalah sebagai berikut :

1. Masyarakat mendapatkan pengetahuan baru tentang bagaimana mencegah penularan penyakit ISPA dan faktor resiko terserang penyakit ISPA dengan diadakannya kegiatan tersebut.

2. Masyarakat yang terkena gejala ISPA langsung mendapatkan bantuan masker standar.

3. Tersedia media promosi kesehatan berupa spanduk, banner dan leaflet.

4. Mengetahui jumlah pasien yang memahami tentang ISPA, cara pengobatan dan pencegahannya dan diperoleh hasil dari 50 pasien yang mengikuti kegiatan tersebut, $80 \%$ pasien menjadi paham mengenai ISPA.

\section{UCAPAN TERIMA KASIH}

Ucapan terimakasih kami sampaikan kepada Pusat Penelitian dan Pengabdian Masyarakat STIKes Hang Tuah Pekanbaru sebagai pemberi dana dalam kegiatan pengabdian masyarakat yang telah dilaksanakan pada bulan November 2019. Serta ucapan terimakasih kepada Puskesmas Kecamatan Limapuluh Kota
Pekanbaru yang telah memberikan kesempatan dalam pelaksanaan pengabdian masyarakat.

\section{DAFTAR PUSTAKA}

[1]. Adesanya, O. A., \& Chiao, C. (2017). Environmental risks associated with symptoms of acute respiratory infection among preschool children in North-Western and SouthSouthern Nigeria Communities. International Journal of Environment Research and Public Health, 14(11), $1-10$

[2]. Akinyemi, J. O., \& Morakinyo, O. M. (2018). Household environment and symptoms of childhood acute respiratory tract infections in Nigeria, 2003-2013: a decade of progress and stagnation. BMC Infectious Diseases, 18(1), 1-12. https://doi.org/10.1186/s12879-018$\underline{3207-5}$

[3]. Basuki PP, Febriani H 2017. Hubungan Antara Kriteria Perokok dengan Kejadian Infeksi Saluran Pernapasan Akut (ISPA) pada Balita di Wilayah Kerja Kecamatan Prambanan Yogyakarta. 679-687.

[4]. Cakmak, S., Hebbern, C., Cakmak, J. D., \& Vanos, J. (2016). The modifying effect of socioeconomic status on the relationship between traffic, air pollution and respiratory health in elementary schoolchildren. Journal of Environmental Management, 177, 1-8.

[5]. Darmawan M, Kumala D, Arsesiana A 2016. Hubungan Tingkat Pengetahuan dan Sikap Ibu dalam Pemberian ASI Eksklusif dengan Kejadian ISPA pada Bayi Usia 1-12. Dinamika Kesehatan, 7(2):98-109

[6]. IDAI 2015. Memperingati Hari Pneumonia Dunia. http://www.idai.or.id/artikel/seputa rkesehatan-anak/memperingati hari pneumonia dunia. Diakses tanggal 25 Juni 2019. 
[7]. Kolawole, O., Oguntoye, M., Dam, T., \& Chunara, R. (2017). Etiology of respiratory tract infections in the community and clinic in Ilorin, Nigeria. BMC Research Notes, 10(1), 712. https://doi.org/10.1186/s131040173063-1

[8]. Konsensus 2017. Pertemuan Ahli Infeksi Saluran Pernafasan Atas. https://issuu.com/dhentyf.sa hara/docs/buku_saku_fix. Diakses tanggal 25 Juni 2019.

[9]. Putra, W. S., \& Isnaini Herawati, S. (2017). Penatalaksanaan Fisioterapi Pada Pasien Pneumonia Di Rsp Dr. Ario Wirawan Salatiga. Universitas Muhammadiyah Surakarta. Diperoleh tanggal 20 jjuli 2018 dari http://eprints.ums.ac.id/54522/

[10]. Shibata, T., Wilson, J. L., Watson, L. M., LeDuc, A., Meng, C., La Ane, R., ... \& Maidin, A. (2014). Childhood acute respiratory infections and household environment in an eastern indonesian urban setting. International Journal of Environmental Research and Public Health, 11(12), 12190- 12203. https://doi.org/10.3390/ijerph111212 $\underline{190}$

[11]. Susanti, S. (2017). Analisis program penanggulangan ISPA pada BALITA di Puskesmas sungai lansek tahun 2017. Universitas Andalas.

[12]. Wahyuningsih S 2017. Infeksi Saluran Pernafasan Akut (ISPA) pada Balita di Wilayah Pesisir Desa Kore Kecamatan

[13]. WHO. (2016). Pneumonia. Geneva: World Health Organization. Retrieved September 22, 2018, from http://www.who.int 